\title{
Performance of Lactating Dairy Cows Fed Whole Cottonseed with Elevated Concentrations of Free Fatty Acids in the Oil
}

\author{
H. M. Sullivan, ${ }^{1, *}$ J. K. Bernard, ${ }^{2}$ H. E. Amos, ${ }^{1}$ and T. C. Jenkins ${ }^{3}$ \\ ${ }^{1}$ Department of Animal and Dairy Science, The University of Georgia, Athens 30602 \\ ${ }^{2}$ Department of Animal and Dairy Science, The University of Georgia, Tifton 31794 \\ ${ }^{3}$ Department of Animal and Veterinary Sciences, Clemson University, Clemson, SC 29634
}

\begin{abstract}
Twenty-four multiparous cows were used in a 10-wk randomized block design trial to evaluate the effects of feeding whole cottonseed (WCS) containing increasing concentrations of free fatty acids (FFA) in the oil on nutrient intake and digestibility, milk yield and composition, and select plasma metabolites. Two lots of WCS containing either 3 or $12 \%$ FFA were blended to provide WCS with 3, 6, 9, and 12\% FFA. Cottonseeds were included in the wheat silage-based total mixed ration at $12.5 \%$ of dry matter (DM). There was no difference in intakes of DM, crude protein (CP), or neutral detergent fiber; yield of milk; or percentages of milk protein, lactose, or SNF. Milk fat percentage was lowest for the diet containing WCS with 6\% FFA. Concentrations of individual milk fatty acids C6:0 decreased and C16:1 increased linearly as FFA in WCS increased. A cubic response was observed for concentrations of C8:0, C10:0, and C12:0 because of higher concentrations when diets contained WCS with 6\% FFA than 3 and $12 \%$ FFA, which were higher than 9\% FFA. Intake and apparent total tract digestibility of acid detergent fiber increased linearly as FFA concentration in WCS increased. Apparent NDF digestibility was highest for diets containing WCS with 3 and 6\% FFA; CP digestibility was highest with WCS containing 3 and 9\% FFA. Differences in milk fatty acid concentration and nutrient digestibility suggest minor changes in rumen fermentation; however, feeding WCS with up to $12 \%$ FFA did not negatively impact nutrient intake and digestibility or milk yield or composition.
\end{abstract}

(Key words: whole cottonseed, free fatty acids, milk yield, nutrient digestibility)

Abbreviation key: EE = ether extract, FA = fatty acids, $\mathbf{W C S}=$ whole cottonseed.

Received April 9, 2003.

Accepted November 8, 2003.

Corresponding author: J. K. Bernard; e-mail: jbernard@tifton.uga.edu.

*Current address: MSC 3AE, P. O. Box 30003, Las Cruces, NM 88003.

\section{INTRODUCTION}

Whole cottonseed (WCS) is commonly included in the diet of lactating dairy cattle as a source of fat, protein, and fiber. The supplemental fat from WCS increases the energy density of the diet in support of higher milk yield and provides a source of effective fiber. High levels of unsaturated fatty acids (FA) in the diet are toxic to certain rumen microbes and can coat feed particles, preventing fibrolytic microbes from attaching to fiber and depressing fiber digestion (MacLeod and $\mathrm{Bu}-$ chanan-Smith, 1972; Eastridge and Firkins, 1991). In contrast to other fat sources, WCS can be fed at rates up to $15 \%$ of the diet without drastically disturbing fiber digestion because the FA contained in the seed are released slowly in the rumen and biohydrogenated; therefore, they are not toxic (Moore et al., 1986).

According to rules published by the National Cottonseed Products Association (NCPA, 1997), WCS used for oil production cannot contain more than $1.8 \%$ FFA in the oil. Typically, WCS that is considered undesirable for oil production is often sold as livestock feed. Previous research suggested that the concentration of unsaturated FFA may be responsible for disruption of normal rumen fermentation (Jenkins, 1993). Because the oil in WCS is $70 \%$ unsaturated and is completely hydrolyzed to FA in the rumen (Keele et al., 1989), high levels of FFA in WCS may have a negative effect on fiber digestion (Martinez et al., 1991; DePeters and Cant, 1992).

The ability of lipid sources to alter milk FA profiles is well documented (Hermansen, 1995). Various lipid sources, especially those containing polyunsaturated fat, have been implicated in spontaneous oxidation and off-flavors in milk (Timmons et al., 2001). Because of the high level of polyunsaturated FA in WCS and the possibility of reduced biohydrogenation of FFA in the rumen, WCS containing elevated concentrations of FFA could be detrimental to milk quality. The objectives of this study were to determine the effects of feeding WCS with elevated concentrations of FFA in the oil on nutrient intake and digestibility, milk yield and composition, and selected blood metabolites of lactating dairy cows. 
Table 1. Ingredient and chemical composition of experimental diets containing whole cottonseed (WCS) with increasing concentrations of free fatty acids (FFA) in the oil.

\begin{tabular}{|c|c|c|c|c|}
\hline & \multicolumn{4}{|c|}{ FFA in oil of WCS } \\
\hline & $3 \%$ & $6 \%$ & $9 \%$ & $12 \%$ \\
\hline Ingredient & \multicolumn{4}{|c|}{$\longrightarrow(\%$ of $\mathrm{DM}) \longrightarrow$} \\
\hline Wheat silage & 44.9 & 44.9 & 44.9 & 44.9 \\
\hline Ground corn & 24.5 & 24.5 & 24.5 & 24.5 \\
\hline $3 \%$ FFA WCS & 12.5 & 8.3 & 4.2 & \\
\hline $12 \%$ FFA WCS & & 4.2 & 8.3 & 12.5 \\
\hline Soybean hulls & 3.0 & 3.0 & 3.0 & 3.0 \\
\hline Soybean hulls (48\% CP) & 9.2 & 9.2 & 9.2 & 9.2 \\
\hline Protein supplement ${ }^{1}$ & 3.8 & 3.8 & 3.8 & 3.8 \\
\hline Mineral-vitamin premix ${ }^{2}$ & 2.1 & 2.1 & 2.1 & 2.1 \\
\hline \multicolumn{5}{|l|}{ Chemical } \\
\hline \multirow[t]{2}{*}{$\mathrm{DM}$} & 57.5 & 57.4 & 57.8 & 57.8 \\
\hline & \multicolumn{4}{|c|}{$\longrightarrow(\%$ of $\mathrm{DM})-$} \\
\hline $\mathrm{CP}$ & 19.8 & 18.8 & 19.6 & 19.0 \\
\hline $\mathrm{NDF}$ & 46.5 & 47.2 & 46.8 & 47.8 \\
\hline $\mathrm{ADF}$ & 29.8 & 29.1 & 28.4 & 29.6 \\
\hline $\mathrm{EE}^{3}$ & 6.3 & 6.3 & 6.4 & 6.4 \\
\hline $\mathrm{NE}_{\mathrm{L}},{ }^{4} \mathrm{Mcal} / \mathrm{kg}$ & 1.6 & 1.6 & 1.6 & 1.6 \\
\hline
\end{tabular}

${ }^{1}$ Protein supplement was composed of $60 \%$ Menhaden fish meal and $40 \%$ distillers grains with solubles.

${ }^{2}$ Premix contained $34 \% \mathrm{CP}$ from urea, $24.50 \% \mathrm{Ca}, 3.68 \% \mathrm{P}, 1.27 \%$ $\mathrm{Mg}, 0.08 \% \mathrm{~K}, 3.03 \% \mathrm{Na}, 4.60 \% \mathrm{Cl}, 0.31 \% \mathrm{~S}, 11.67 \mathrm{ppm}$ of $\mathrm{Co}, 665$ ppm of Cu, $4622 \mathrm{ppm}$ of Fe, $58 \mathrm{ppm}$ of I, $2039 \mathrm{ppm}$ of Mn, $14.69 \mathrm{ppm}$ of Se, $1943 \mathrm{ppm}$ of $\mathrm{Zn}, 60,360 \mathrm{IU} / \mathrm{kg}$ of vitamin A, 24,145 IU/kg vitamin $\mathrm{D}$, and $300 \mathrm{IU} / \mathrm{kg}$ of vitamin $\mathrm{E}$.

${ }^{3} \mathrm{EE}=$ ether extract.

${ }^{4}$ Determined using NRC (2001) values.

\section{MATERIALS AND METHODS}

Two lots of WCS differing in FFA concentrations were obtained from warehouses in South Georgia and transported to The University of Georgia Dairy Center in Athens, GA. One lot of WCS contained 3\% FFA, and the second lot contained 12\% FFA as determined by the procedure outlined by NCPA (1997). Experimental diets, fed as TMR (Table 1), were formulated for a 670 $\mathrm{kg}$ lactating cow producing $32 \mathrm{~kg} / \mathrm{d}$ of milk $(3.5 \%$ milk fat and $3.3 \%$ protein) with a daily gain of $0.45 \mathrm{~kg}$. Dietary treatments consisted of 4 concentrations of FFA in WCS and were achieved by stepwise substitution of the low FFA WCS with high FFA WCS.

Twenty-four multiparous lactating Holstein cows were used in a 10 -wk randomized block design trial from March 28 through June 6, 2001. Cows were managed according to procedures approved by The University of Georgia Institutional Animal Care and Use Committee. Cows were fed the control diet for $14 \mathrm{~d}$ prior to the start of the 56-d trial period. Cows were housed in a free stall barn and individually fed twice daily behind Calan gates (American Calan, Inc., Northwood, NH) at $105 \%$ of the previous day's intake. Cows were assigned to 1 of 6 blocks according to milk yield $(\overline{\mathrm{x}}=37.8$; range
32.7 to $49.9 \mathrm{~kg} / \mathrm{d}$ ). Cows within blocks were assigned randomly to 1 of 4 dietary treatments at the end of the 14-d preliminary period. The amount of feed offered and orts were recorded daily. Feed and orts were sampled daily and composited weekly by treatment. No significant sorting was observed among cows based on visual analysis of orts. Pooled samples were dried at $55^{\circ} \mathrm{C}$ for $72 \mathrm{~h}$, ground to pass through a $2-\mathrm{mm}$ screen using a Wiley mill screen (Arthur W. Thomas Co., Philadelphia, PA), and stored for analyses.

Milk yield was recorded at each milking (2 times daily). Milk samples were collected at each milking during the pretrial and at wk 2, 3, 4, 5, and 6 and pooled by cow within each week for analyses of milk fat and protein using infrared spectrometry (DHIA, Belleview, FL). Total solids were determined by lyophilizing duplicate $10-\mathrm{mL}$ aliquots (Virtis Freezemobile 12; Virtis Co Inc., Gardiner, NY). The solids were then ashed for 3 $\mathrm{h}$ at $510^{\circ} \mathrm{C}$ to determine the mineral content. Lactose percentage was calculated by difference. During wk 5 and 7, milk fat was isolated from an aliquot by centrifugation at $21,000 \times g$ for 15 min. Milk FA were converted to methyl esters, and FA profile was determined by the method of Kramer et al. (1997) using Hewlett Packard $5890 \mathrm{~A}$ equipped with a $30-\times 0.25-\mathrm{mm}$ (i.d.) polyamino glycol capillary column (Spelco Inc., Bellefonte, PA). Cows were weighed on 3 consecutive $d$ during the last week of the pretrial period and the last week of experimental period.

Fecal grab samples were collected on 3 consecutive $\mathrm{d}$ during wk 5 at 12 -h intervals. Sampling schedule was advanced $2 \mathrm{~h}$ each day during collection period. Samples were dried, composited by cow, ground to pass through a 2-mm screen, and stored for analyses.

Nitrogen was determined using a Leco FP528 (Leco Corp., St. Joseph, MI), and CP was calculated (percentage of $\mathrm{N} \times 6.25)$. Ether extract $(\mathbf{E E})$ of feed and orts was determined by soxhlet extraction with petroleum ether. The NDF and ADF of the TMR, orts, and feces were determined by the method of Robertson and Van Soest (1981) using an Ankom 220 Fiber Analyzer (Ankom Technology Co., Fairport, NY). Nutrient digestibility was calculated using indigestible $\mathrm{ADF}$ as a marker (Henderson et al., 1985) using a Daisy II 200 Rumen Fermentor (Ankom Technology Co.). Nutrient intake and apparent digestibility coefficients were corrected for orts.

Blood samples were collected from the coccygeal vein in preheparinized and $\mathrm{NaF}$ tubes at 0,2 , and $4 \mathrm{~h}$ after the a.m. feeding during wk 2 of the pretrial period and wk 3 and 6 of the experimental period. Samples were prepared for glucose and insulin analyses by refrigeration $\left(8 \mathrm{~h}\right.$ at $\left.4^{\circ} \mathrm{C}\right)$ and centrifugation $(3000 \times g, 20 \mathrm{~min})$. Plasma glucose was analyzed by a Tinder colorimetric 
method (procedure \#315; Sigma, St. Louis, MO). Insulin was determined by radioimmunoassay using a ${ }^{125} \mathrm{I}$ competitive binding method (ICN Pharmaceuticals Inc., Costa Mesa, CA). Plasma samples from wk 6 were pooled and prepared for AA analysis by deproteinizing with $5 \%$ sulfasalicylic acid, freezing for $12 \mathrm{~h}$ at $-4^{\circ} \mathrm{C}$, and centrifuged at $5000 \times g$ for $20 \mathrm{~min}$ (Amos et al., 1976). Plasma AA were determined by HPLC using a Beckman 1600 amino acid analyzer using norleucine as an internal standard (Beckman Instruments Inc., Fullerton, CA).

The DMI, milk yield, and milk composition data were analyzed using the PROC MIXED procedures of SAS (1996). The statistical model included the effect of treatment, week, and treatment $\times$ week interaction. Corresponding data from the preliminary week were included as a covariate for each variable, except milk FA concentration, along with DIM. Cow within treatment was included in the model as a random effect. A compound symmetry covariance structure was specified. Nutrient intake, apparent digestibility, and plasma AA data were analyzed using the GLM procedure of SAS (1996). Linear, quadratic, and cubic effects of FFA concentration were tested using one degree of freedom using contrast statements.

\section{RESULTS AND DISCUSSION}

The experimental diets contained similar concentrations of nutrients (Table 1). The two lots of WCS (Table 2 ) were similar in composition except that the $12 \%$ FFA had slightly higher concentrations of C16:0 and slightly lower concentrations of EE and C18:2.

Average DMI was similar for all treatments during the 8-wk trial (Table 3); however, there was a treatment $\times$ week interaction $(P<0.05)$. The interaction was due to an increase in DMI for cows fed WCS containing 6,9 , and $12 \%$ FFA during wk 7 and 8; whereas DMI remained constant for cows fed the diet containing WCS with 3\% FFA (Figure 1). These results indicate that increasing concentrations of FFA in WCS do not negatively affect the acceptability of the diet.

Milk yield was similar for all treatments and averaged $33.5 \mathrm{~kg} / \mathrm{d}$. Milk fat percentage was higher $(P<$ 0.05 ) for cows fed the 9\% FFA WCS and lowest for cows fed the 6\% FFA WCS compared with the other treatments. Yield of milk fat was similar for all treatments, so the higher milk fat percentage observed with 9\% FFA WCS was most likely due to dilution as milk yield was numerically lower. No differences were observed among treatments in percentage or yield of milk protein, lactose, ash, total solids, and SNF or yield of energy-corrected milk.
Table 2. Chemical composition of whole cottonseed (WCS) containing different concentrations of FFA in the oil.

\begin{tabular}{|c|c|c|}
\hline & \multicolumn{2}{|c|}{ FFA in oil of WCS } \\
\hline & $3 \%$ & $12 \%$ \\
\hline & $\longrightarrow$ & \\
\hline DM & 88.8 & 88.0 \\
\hline $\mathrm{CP}$ & 26.7 & 24.8 \\
\hline NDF & 43.2 & 43.3 \\
\hline $\mathrm{ADF}$ & 30.3 & 30.8 \\
\hline $\mathrm{EE}^{1}$ & 17.0 & 16.2 \\
\hline FFA & 3.0 & 12.0 \\
\hline C14:0 & 0.70 & 0.72 \\
\hline C16:0 & 22.31 & 24.76 \\
\hline C16:1 & 0.52 & 0.57 \\
\hline C18:0 & 2.23 & 2.45 \\
\hline C18:1 & 14.97 & 14.91 \\
\hline C18:2 & 58.53 & 56.22 \\
\hline C18:3 & 0.15 & 0.14 \\
\hline C20:0 & 0.26 & 0.00 \\
\hline C22:0 & 0.16 & 0.00 \\
\hline C24:0 & 0.10 & 0.16 \\
\hline Other & 0.07 & 0.07 \\
\hline
\end{tabular}

${ }^{1} \mathrm{EE}=$ ether extract.

The higher standard error observed for milk yield and energy-corrected milk yield coupled with only 6 cows per treatment increases the difference required to detect a significant difference between treatments. Milk yield was numerically greatest for the diet containing WCS with 6\% FFA and lowest for the diet containing WCS with 9\% FFA, but energy-corrected milk yield was numerically higher for diets containing WCS greater than 3\% FFA. These data suggest that feeding WCS with up to $12 \%$ FFA should not negatively impact milk yield; however, additional research is required to determine the impact of feeding WCS with even higher concentrations of FFA.

Table 3. Dry matter intake and milk yield and composition of lactating Holstein cows fed diets containing whole cottonseed (WCS) with increasing concentrations of FFA in the oil.

\begin{tabular}{lccccl}
\hline & \multicolumn{4}{c}{ FFA in oil of WCS } \\
\cline { 2 - 5 } & $3 \%$ & $6 \%$ & $9 \%$ & $12 \%$ & SE \\
\hline DMI, kg/d & 21.5 & 22.8 & 22.1 & 23.0 & 0.7 \\
Milk, kg/d & 32.9 & 35.7 & 32.0 & 33.8 & 1.9 \\
Fat, ${ }^{\circ} \%$ & 3.48 & 3.32 & 3.67 & 3.41 & 0.08 \\
Protein, \% & 2.63 & 2.74 & 2.85 & 2.81 & 0.09 \\
Lactose, \% & 5.39 & 5.30 & 5.37 & 5.22 & 0.15 \\
TS, \% & 12.22 & 12.01 & 12.61 & 12.18 & 0.25 \\
Ash, \% & 0.69 & 0.71 & 0.71 & 0.69 & 0.01 \\
SNF, \% & 8.72 & 8.74 & 0.92 & 0.74 & 0.18 \\
ECM, ${ }^{1} \mathrm{~kg} / \mathrm{d}$ & 32.7 & 33.2 & 33.5 & 33.1 & 1.6 \\
\hline
\end{tabular}

${ }^{1} \mathrm{ECM}=$ energy-corrected milk.

${ }^{a}$ Cubic response to increasing concentrations of FFA in WCS $(P<$ $0.05)$. 


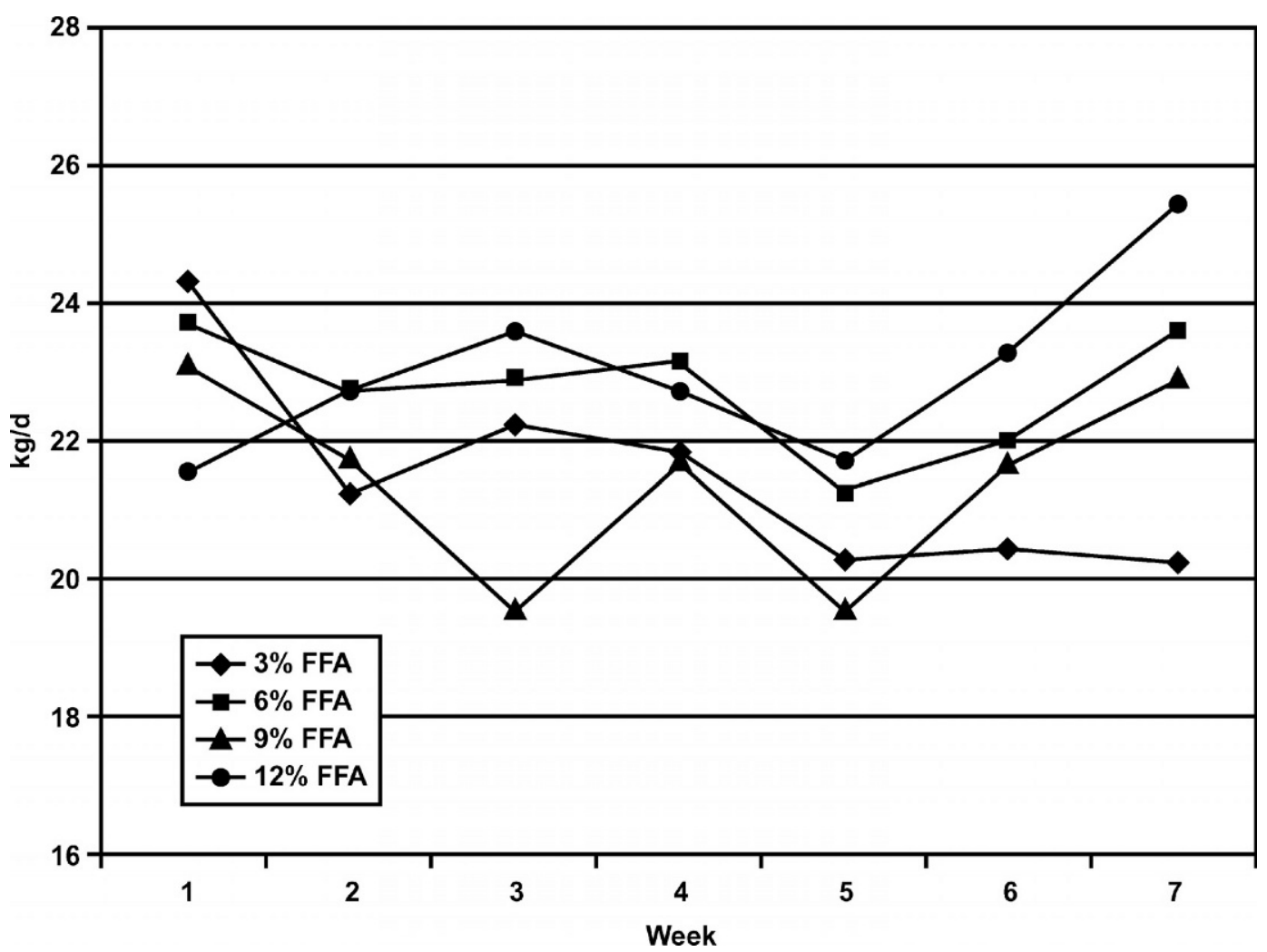

Figure 1. Interaction of FFA concentration in the oil of whole cottonseed and week on DMI (SE $=1.0 \mathrm{~kg} / \mathrm{d}, P<0.03)$.

Increased milk fat percentage and decreased milk protein percentage have been reported when WCS are supplemented to the diet (Coppock et al., 1987), but composition is not typically altered by type of cottonseed (Santos et al., 2002) or amount fed (Coppock et al., 1987). The change in BW during the 8-wk trial did not differ by treatment $(-11.4,18.7,6.0$, and $10.8 \mathrm{~kg}$ for WCS with FFA of $3,6,9$, and $12 \%$, respectively). In contrast to our results, Bruckmaier et al. (1998) reported a decrease in milk fat percentage when a prilled FFA supplement was fed. Compared with the hydrogenated triglyceride supplement, the prilled FFA supplement those researchers fed had much higher concentrations of $\mathrm{C} 16: 0$ and lower concentrations of $\mathrm{C} 18: 1$, which has reduced milk fat percentage (Palmquist and Jenkins, 1980).

Individual milk FA concentrations are presented in Table 4. Concentrations of C6:0 decreased linearly ( $P$ $<0.05)$ as FFA in WCS increased. A cubic response was observed for C8:0 $(P<0.05), \mathrm{C} 10: 0(P<0.02), \mathrm{C} 12: 0(P<$ 0.01 ), and total short-chain FA because concentrations were highest for 6\% FFA and lowest for 9\% FFA. Concentrations of $\mathrm{C} 16: 0(P<0.05), \mathrm{C} 16: 1(P<0.05)$, and total medium-chain FA $(P<0.01)$ increased linearly in response to WCS with increasing FFA. Individual and total long-chain FA, total unsaturated FA, and total saturated FA were similar for all treatments.

Supplemental WCS has reduced concentrations of C6 through C14 milk FA because of the inhibition of mammary de novo FA synthesis (Palmquist et al., 1993; Wu et al., 1994; Jenkins et al., 1996). The increase in FFA did not appear to alter synthesis of short-chain FA greatly, although differences were noted for diets containing WCS with 6 and 9\% FFA. Increasing FFA in WCS does not appear to alter medium- or long-chain FA. Generally off-flavors caused by spontaneous autooxidation are associated with increases in milk C18:2 and C18:3 FA, and these FA are often increased with addition of oilseed to the diet (Hermansen, 1995). Concentrations of C18:2 and C18:3 were similar for all diets in the current study, suggesting that increased FFA in WCS should not cause any off-flavors in the milk.

Nutrient intake and total tract apparent digestibility coefficients as measured during wk 5 are presented in Table 5. No differences were observed in intake of DM, $\mathrm{CP}$, and NDF; however, intake of ADF increased linearly $(P<0.02)$ as FFA in WCS increased. No differences were observed in the apparent digestibility of DM among treatments. The CP digestibility was lowest for WCS with 6\% FFA and highest for WCS with 9\% FFA, 
Table 4. Fatty acid (FA) concentrations in milk of lactating Holstein cows fed diets containing whole cottonseed (WCS) with increasing concentrations of FFA in the oil.

\begin{tabular}{|c|c|c|c|c|c|}
\hline & \multicolumn{4}{|c|}{ FFA in oil of WCS } & \multirow[b]{2}{*}{$\mathrm{SE}$} \\
\hline & $3 \%$ & $6 \%$ & $9 \%$ & $12 \%$ & \\
\hline & \multicolumn{4}{|c|}{$\longrightarrow(\%$ of total FA $) \longrightarrow$} & \\
\hline $\mathrm{C} 4: 0$ & 3.62 & 3.61 & 3.28 & 3.40 & 0.15 \\
\hline $\mathrm{C} 6: 0^{\mathrm{a}}$ & 2.38 & 2.55 & 2.25 & 2.27 & 0.07 \\
\hline $\mathrm{C} 8: 0^{\mathrm{b}}$ & 1.30 & 1.49 & 1.25 & 1.26 & 0.05 \\
\hline $\mathrm{C} 10: 0^{\mathrm{c}}$ & 2.56 & 3.06 & 2.50 & 2.60 & 0.10 \\
\hline C11:0 & 0.04 & $<0.01$ & 0.04 & 0.04 & 0.02 \\
\hline $\mathrm{C} 12: 0^{\mathrm{c}}$ & 2.70 & 3.23 & 2.69 & 2.79 & 0.10 \\
\hline Total C4-12 FA ${ }^{b}$ & 12.60 & 13.94 & 12.01 & 12.36 & 0.22 \\
\hline C14:0 & 10.13 & 10.81 & 10.31 & 10.36 & 0.21 \\
\hline C14:1 & 1.22 & 1.30 & 1.29 & 1.22 & 0.08 \\
\hline C15:0 & 0.90 & 0.90 & 0.89 & 0.90 & 0.02 \\
\hline $\mathrm{C} 16: 0^{\mathrm{a}}$ & 28.74 & 27.94 & 30.01 & 30.33 & 0.74 \\
\hline $\mathrm{C} 16: 1^{\mathrm{a}}$ & 0.94 & 0.92 & 1.20 & 1.18 & 0.09 \\
\hline $\mathrm{C} 17: 0$ & 0.52 & 0.52 & 0.51 & 0.51 & 0.02 \\
\hline Total medium-chain $\mathrm{FA}^{\mathrm{a}, \mathrm{b}}$ & 42.45 & 42.39 & 44.21 & 44.50 & 0.60 \\
\hline C18:0 & 14.97 & 14.37 & 14.27 & 14.43 & 0.59 \\
\hline $\mathrm{t} 18: 1$ & 2.01 & 2.13 & 2.03 & 2.17 & 0.08 \\
\hline C18:1 & 20.70 & 19.60 & 20.30 & 19.40 & 0.65 \\
\hline C18:2 & 2.09 & 2.26 & 2.11 & 2.07 & 0.08 \\
\hline C18:2 c9t11 & 0.36 & 0.37 & 0.38 & 0.39 & 0.06 \\
\hline C18:3 & 0.37 & 0.38 & 0.36 & 0.36 & 0.05 \\
\hline Other CLA & 0.12 & 0.13 & 0.12 & 0.14 & 0.03 \\
\hline C20:0 & 0.24 & 0.21 & 0.24 & 0.23 & 0.01 \\
\hline $\mathrm{C} 22: 0$ & 0.08 & 0.07 & 0.08 & 0.06 & 0.02 \\
\hline C22:1 & 0.08 & 0.05 & 0.05 & 0.04 & 0.02 \\
\hline Total long-chain $\mathrm{FA}^{2}$ & 41.02 & 39.57 & 39.94 & 39.29 & 0.60 \\
\hline Unidentified FA & 3.93 & 4.10 & 3.84 & 3.85 & \\
\hline Unsaturated FA & 27.88 & 27.15 & 27.85 & 26.93 & 0.51 \\
\hline Saturated FA & 68.26 & 68.71 & 68.32 & 69.23 & 0.58 \\
\hline
\end{tabular}

${ }^{a}$ Linear response to increasing concentrations of FFA in WCS $(P<0.05)$.

${ }^{\mathrm{b}}$ Cubic response to increasing concentrations of FFA in WCS $(P<0.05)$.

${ }^{\mathrm{c}}$ Cubic response to increasing concentrations of FFA in WCS $(P<0.02)$.

${ }^{\mathrm{d}}$ Linear response to increasing concentrations of FFA in WCS $(P<0.01)$.

${ }^{1}$ Fatty acids with 14 to 18 carbons.

${ }^{2}$ Fatty acids greater than 18 carbons.

Table 5. Nutrient intake and apparent total tract digestibility of lactating Holstein cows fed diets containing whole cottonseed (WCS) with increasing concentrations of FFA in the oil during wk 5.

\begin{tabular}{lccccc}
\hline & \multicolumn{4}{c}{ FFA in oil of WCS } \\
\cline { 2 - 5 } & $3 \%$ & $6 \%$ & $9 \%$ & $12 \%$ & SE \\
\hline Intake, kg/d & 21.2 & 23.0 & 21.8 & 21.9 & 0.9 \\
DM & 3.4 & 3.4 & 3.6 & 3.3 & 0.1 \\
CP & 6.01 & 6.67 & 6.60 & 7.16 & 0.6 \\
NDF & 10.4 & 11.6 & 10.2 & 10.7 & 0.4 \\
ADF & & & & & \\
Apparent digestibility, \% & 50.3 & 51.2 & 49.7 & 49.6 & 1.0 \\
DM & 54.1 & 48.0 & 53.2 & 46.7 & 1.1 \\
CP & 39.7 & 42.8 & 35.4 & 38.6 & 0.7 \\
NDF $^{\mathrm{c}}$ & 35.1 & 36.7 & 39.9 & 45.6 & 1.6 \\
ADF $^{\mathrm{b}}$ & & & & & \\
\hline
\end{tabular}

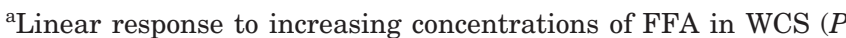
$<0.05)$.

${ }^{\mathrm{b}}$ Linear response to increasing concentrations of FFA in WCS $(P$ $<0.01$ )

${ }^{\mathrm{c}}$ Cubic reponse to increasing concentrations of FFA in WCS $(P<$ $0.05)$. resulting in a cubic response $(P<0.05)$. The NDF digestibility was highest for WCS with $6 \%$ FFA and lowest for WCS with 9\% FFA, resulting in a cubic response ( $P$ $<0.05)$. Apparent digestibility of ADF increased linearly $(P<0.01)$ as FFA in WCS increased.

Plascencia et al. (1999) did not observe any negative effect on the total tract digestibility of nutrients when yellow grease containing increasing concentrations of FFA were fed to steers. However, the increased ADF intake with increasing FFA levels in our trial might have minimized any negative effects at the highest levels of FFA in WCS. Others have shown that increasing the fiber content of a diet can mitigate the fermentation problems normally associated with increased unprotected dietary fats (Mir, 1988; Doreau et al., 1991; Tackett et al., 1996). The reason for the differences in CP digestibility is not apparent, but might reflect nonsignificant differences in intake that parallel the digestibility coefficients. 
Table 6. Amino acid concentrations of diets containing whole cottonseed (WCS) with increasing concentrations of FFA in the oil.

\begin{tabular}{lrrrr}
\hline & \multicolumn{4}{c}{ FFA in oil of WCS } \\
\cline { 2 - 5 } & $3 \%$ & $6 \%$ & $9 \%$ & $12 \%$ \\
\cline { 2 - 5 } & \multicolumn{4}{c}{$(\mathrm{mg}$ AA/g of DM) } \\
\cline { 2 - 6 } Arginine & 9.7 & 9.9 & 9.5 & 8.6 \\
Histidine & 3.5 & 3.5 & 3.5 & 3.3 \\
Isoleucine & 6.6 & 6.7 & 6.4 & 6.3 \\
Leucine & 11.4 & 11.4 & 11.4 & 10.7 \\
Lysine & 6.0 & 6.0 & 5.8 & 5.6 \\
Methionine & 2.3 & 2.3 & 2.2 & 2.0 \\
Phenylalanine & 6.6 & 6.7 & 6.5 & 6.2 \\
Threonine & 5.6 & 5.7 & 5.7 & 5.3 \\
Valine & 0.4 & 0.4 & 0.5 & 0.4 \\
Total essential AA & 52.1 & 52.6 & 51.5 & 48.4 \\
Alanine & 9.5 & 9.6 & 9.5 & 8.9 \\
Aspartamine & 12.8 & 13.0 & 12.8 & 12.4 \\
Cystine & 3.8 & 3.8 & 3.7 & 3.6 \\
Glutamine & 26.2 & 26.3 & 26.0 & 24.9 \\
Glycine & 7.4 & 7.6 & 7.5 & 7.4 \\
Proline & 10.8 & 10.8 & 10.8 & 10.2 \\
Serine & 7.5 & 7.5 & 7.7 & 7.1 \\
Tyrosine & 4.7 & 4.6 & 4.7 & 4.3 \\
Total non-essential AA & 82.7 & 83.2 & 82.7 & 78.8 \\
Total AA & 134.8 & 135.8 & 134.2 & 127.2 \\
\hline
\end{tabular}

There were no differences among treatments in average plasma glucose concentrations, which averaged $54.5 \mathrm{mg} / \mathrm{dL}$ (data not shown). Plasma insulin concentrations were $18.0,20.5,19.7$, and $17.4 \mu \mathrm{U} / \mathrm{mL}$ for WCS with FFA of $3,6,9$, and $12 \%$, respectively. A quadratic effect $(P<0.005)$ was observed for plasma insulin because of higher concentrations when WCS containing either 6 or $9 \%$ FFA were fed compared with that when WCS containing either 3 or $12 \%$ FFA were fed. An interaction $(P<0.001)$ of week $\times$ sampling time was observed for both glucose and insulin concentrations because of a shift in eating patterns. As the trial progressed, temperatures increased, and the cows ate a greater proportion of their DM after the p.m. feeding.

Dietary concentrations of AA are presented in Table 6 , and plasma AA concentrations measured during wk 6 are presented in Table 7. A quadratic response was observed for concentrations of isoleucine $(P<0.01)$, leucine $(P<0.03)$, valine $(P<0.01)$, and total branch edchain AA $(P<0.01)$ because of lower concentrations when WCS with 6 and 9\% FFA were fed. Plasma lysine exhibited a cubic response $(P<0.02)$ because of higher concentrations with 3 and 9\% FFA in WCS than with 6 and 12\% FFA in WCS. Phenylalanine and ornithine

Table 7. Plasma amino acid concentrations of lactating Holstein cows fed diets containing whole cottonseed (WCS) with increasing concentrations of FFA in the oil.

\begin{tabular}{|c|c|c|c|c|c|}
\hline & \multicolumn{4}{|c|}{ FFA in oil of WCS } & \multirow[b]{2}{*}{$\mathrm{SE}$} \\
\hline & $3 \%$ & $6 \%$ & $9 \%$ & $12 \%$ & \\
\hline & & - $(\mathrm{n}$ & ) & 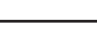 & \\
\hline Arginine & 8.64 & 7.26 & 7.34 & 7.15 & 0.50 \\
\hline Histidine & 3.93 & 3.14 & 3.50 & 3.54 & 0.35 \\
\hline Isoleucine $\mathrm{e}^{\mathrm{b}}$ & 23.79 & 17.58 & 17.36 & 19.26 & 1.23 \\
\hline Leucine $^{c}$ & 15.18 & 11.22 & 11.28 & 11.86 & 0.94 \\
\hline Lysine $^{\mathrm{d}}$ & 8.78 & 6.79 & 7.40 & 5.82 & 0.63 \\
\hline Methionine & 4.12 & 3.84 & 3.84 & 3.97 & 0.19 \\
\hline Phenylalanine $^{a}$ & 3.91 & 3.35 & 3.37 & 3.01 & 0.18 \\
\hline Threonine & 7.87 & 6.70 & 8.17 & 7.72 & 0.53 \\
\hline Tryptophan & 2.97 & 7.12 & 7.38 & 5.48 & 2.60 \\
\hline Valine $^{\mathrm{b}}$ & 25.84 & 18.44 & 17.44 & 20.45 & 1.49 \\
\hline Total essential AA & 105.03 & 85.43 & 87.09 & 87.50 & 5.15 \\
\hline Alanine & 20.09 & 19.30 & 18.34 & 17.88 & 1.85 \\
\hline Cysteine & 4.86 & 5.05 & 4.85 & 5.06 & 0.17 \\
\hline Cystithionine $^{\mathrm{a}}$ & 0.19 & 0.21 & 0.20 & 0.29 & 0.01 \\
\hline Glutamine & 149.38 & 146.58 & 144.38 & 122.25 & 8.56 \\
\hline Glutamate & 5.62 & 5.87 & 5.90 & 5.72 & 0.48 \\
\hline Glycine & 30.01 & 33.27 & 27.66 & 29.64 & 1.70 \\
\hline Ornithine $^{\mathrm{d}}$ & 4.77 & 3.81 & 4.41 & 3.89 & 0.26 \\
\hline Proline & 6.80 & 6.00 & 5.91 & 6.33 & 0.48 \\
\hline Serine & 6.54 & 6.92 & 6.77 & 6.26 & 0.39 \\
\hline Tyrosine & 3.50 & 5.27 & 2.82 & 2.94 & 0.91 \\
\hline Branched-chain $\mathrm{AA}^{\mathrm{b}}$ & 64.81 & 47.24 & 46.09 & 51.56 & 3.48 \\
\hline Total essential $\mathrm{AA}^{\mathrm{a}}$ & 230.01 & 230.48 & 220.94 & 198.73 & 7.92 \\
\hline Total $\mathrm{AA}^{\mathrm{a}}$ & 335.04 & 315.92 & 308.03 & 286.23 & 10.47 \\
\hline
\end{tabular}

${ }^{a}$ Linear response to increasing concentrations of FFA in WCS $(P<0.01)$.

${ }^{\mathrm{b}} \mathrm{Quadratic}$ response to increasing concentrations of FFA in WCS $(P<0.01)$.

${ }^{\mathrm{c}} \mathrm{Quadratic}$ response to increasing concentrations of FFA in WCS $(P<0.05)$.

${ }^{\mathrm{d}}$ Cubic response to increasing concentrations of FFA in WCS $(P<0.01)$. 
concentrations decreased linearly $(P<0.02)$, whereas cystithionine increased linearly $(P<0.01)$, as FFA in WCS increased. Total essential AA $(P<0.07)$, nonessential AA $(P<0.01)$, and total AA $(P<0.01)$ decreased linearly as the concentration of FFA in WCS increased.

Supplemental free soybean oil and whole soybeans have been observed to reduce plasma concentrations of isoleucine, ornithine, and leucine; however, no changes in plasma AA were noted when free oil and WCS were supplemented (Mohamed et al., 1988). Decreased concentrations of plasma branched-chain AA may indicate reduced microbial protein synthesis (Mohamed et al., 1988), which could account for the linear decline in concentrations of total essential and nonessential AA as the FFA in WCS increased. However, the flow of microbial protein to the abomasum was not altered when steers were fed WCS with FFA concentrations of 8 to $14.7 \%$ (Sullivan, 2002). Digestibility of CP was lowest when WCS with either 6 or $12 \%$ FFA were fed, but this did not alter yield of milk or milk protein.

\section{CONCLUSIONS}

Feeding WCS with FFA concentrations up to $12 \%$ does not alter nutrient intake, milk yield, or composition. Minor changes were noted for several short-chain FA in the milk, but, overall, the FA profile was not greatly altered. There was no change in concentrations of C18:2 and C18:3 in milk, suggesting that increased FFA in WCS would not cause any off-flavors in the milk or milk products. Changes in nutrient digestibility and plasma AA concentrations suggest that changes in ruminal fermentation might have occurred, which warrants additional research.

\section{REFERENCES}

Amos, H. E., J. J. Evans, and D. Burdick. 1976. Abomasal protein recovery and microbial protein synthesis in wethers fed high and low quality forage diets. J. Anim. Sci 42:970-976.

Bruckmaier, R. M., L. Gregoretti, F. Jans, D. Faissler, and J. W. Blum. 1998. Longissimus dorsi muscle diameter, backfat thickness, body condition scores and skinfold values related to metabolic and endocrine traits in lactating dairy cows fed crystalline fat or free fatty acids. J. Vet. Med. 45:397-410.

Coppock, C. E., J. K. Lanham, and J. I. Horner. 1987. A review of the nutritive value and utilization of whole cottonseed, cottonseed meal and associated by-products by dairy cattle. Anim. Feed Sci. Technol. 18:89-129.

DePeters, E. J., and J. P. Cant. 1992. Nutritional factors influencing the nitrogen composition of bovine milk: A review. J. Dairy Sci. 75:2043-2070.

Doreau, M., F. Legay, and D. Bauchart. 1991. Effect of source and level of supplemental fat on total and ruminal organic matter and nitrogen digestion in dairy cows. J. Dairy Sci. 74:2233-2242.

Eastridge, M. L., and J. L. Firkins. 1991. Feeding hydrogenated fatty acids and triglycerides to lactating dairy cows. J. Dairy Sci. 74:2610-2616.
Henderson, S. J., H. E. Amos, and J. J. Evans. 1985. Influence of dietary protein concentration and degradability on milk production, composition, and ruminal protein metabolism. J. Dairy Sci. 68:2227-2237.

Hermansen, J. E. 1995. Prediction of milk fatty acid profile in dairy cows fed dietary fat differing in fatty acid composition. J. Dairy Sci. 78:872-879.

Jenkins, T. C. 1993. Lipid metabolism in the rumen. J. Dairy Sci. 76:3851-3863.

Jenkins, T. C., H. G. Bateman, and S. M. Block. 1996. Butylsoyamide increases unsaturation of fatty acids in plasma and milk of lactating dairy cows. J. Dairy Sci. 79:585-590.

Keele, J. W., R. E. Roffler, and K. Z. Beyers. 1989. Ruminal metabolism in non-lactating cows fed whole cottonseed or extruded soybeans. J. Anim. Sci. 67:1612-1622.

Kramer, J. K., V. Fellner, M. E. Dugan, F. D. Sauer, M. M. Mossoba, and M. P. Yurawecz. 1997. Evaluating acid and base catalysts in the methylation of milk and rumen fatty acids with special emphasis on conjugated dienes and total trans fatty acids. Lipids 32:1219-1228.

MacLeod, G. L., and J. G. Buchanan-Smith. 1972. Digestibility of hydrogenated tallow, saturated fatty acids and soybean-supplemented diets by sheep. J. Anim. Sci 35:890-895.

Martinez, N., E. J. DePeters, and D. L Bath. 1991. Supplemental niacin and fat effects on milk composition of lactating Holstein cows. J. Dairy Sci. 74:202-220.

Mir, Z. 1998. A comparison of canola acidulated fatty acids and tallow as supplements to a ground alfalfa diet for sheep. Can. J. Anim. Sci. 68:761-768.

Mohamed, O. E., L. D. Satter, R. R. Grummer, and F. R. Ehle. 1988. Influence of dietary cottonseed and soybean on milk production and composition. J. Dairy Sci. 71:2677-2688.

Moore, J. A., R. S. Swingle, and W. H. Hale. 1986. Effects of whole cottonseed, cottonseed oil, or animal fat on digestibility of wheat straw diets by steers. J. Anim. Sci 63:1267-1273.

NCPA. 1997. Rules of the National Cottonseed Products Association, Inc. Natl. Cottonseed Products Assoc., Memphis, TN.

National Research Council. 2001. Nutrient Requirements of Dairy Cattle. 7th rev. ed. Natl. Acad. Sci., Washington, DC.

Palmquist, D. L., A. D. Beaulieu, and D. M. Barbano. 1993. Feed and animal factors influencing milk fat composition. J. Dairy Sci. 76:1753-1771.

Palmquist, D. L., and T. C. Jenkins. 1980. Fat in lactation rations: A review. J. Dairy Sci. 63:1-14.

Plascencia, A., M. Estrada, and R. A. Zinn. 1999. Influence of free fatty acid content on the feeding value of yellow grease in finishing diets for feedlot cattle. J. Anim. Sci. 77:2603-2609.

Robertson, J. B., and P. J. Van Soest. 1981. The detergent system of analysis and its application to human food. Page 123 in The Analysis of Dietary Fiber. W. P. T. James and O. Theoander, ed. Marcell Dekker, New York, NY.

Santos, J. E. P., M. Villasen̆or, E. J. DePeters, P. H. Robinson, and B. C. Baldwin, Jr. 2002. Type of cottonseed and level of gossypol in diets of lactating dairy cows: Effects on lactation performance and plasma gossypol. J. Dairy Sci. 85:1491-1501.

SAS/STAT Software; Changes and Enhancements Through Release 6.11. 1996. SAS Inst., Inc., Cary, NC.

Sullivan, H. M. 2002. Effect of high free fatty acid cottonseed on production in Holstein cattle. Ph.D. Diss., Univ. Georgia, Athens.

Tackett, V. L., J. A. Bertrand, T. C. Jenkins, F. E. Pardue, and L. W. Grimes. 1996. Interaction of dietary fat and acid detergent fiber diets of lactating dairy cows. J. Dairy Sci. 79:270-275.

Timmons, J. S., W. P. Weiss, D. L. Palmquist, and W. J. Harper. 2001 Relationships among dietary roasted soybeans, milk components, and spontaneous oxidized flavor. J. Dairy Sci. 84:2440-2449.

Wu, Z., J. T. Huber, S. C. Chan, J. M Simas, K. H. Chen, J. G. Vargela, F. Santos, C. Fontes, Jr., and P. Yu. 1994. Effect of source and amount of supplemental fat on lactation and digestion in cows. J. Dairy Sci. 77:1644-1651. 